\title{
Arşiv Dünyasında İmha Sanatı
}

\section{The Fine Art of Destruction in Archival}

\section{Ceyhan Güler, Elektronik Belgelerin İmhası: Teori ve Uygulama, İstanbul: Hiperyayın, 2020, 1.baskı, 351 s. ISBN: 978-605-281-918-0; e-ISBN: 978-605-281-919-7}

\section{Ayşegül Tok ${ }^{1}$}

\author{
Anahtar kelimeler \\ Elektronik belge, elektronik belge yönetimi, elektronik belgenin imha yöntem ve teknikleri
}

Keywords

Electronic records, electronic records management, methods and techniques of destruction for electronic records

İstanbul Üniversitesi Edebiyat Fakültesi Bilgi ve Belge Yönetimi Bölümü Arşivcilik Anabilim Dalı'nda Araştırma Görevlisi olarak görev yapmakta olan Dr. Ceyhan Güler tarafından kaleme alınan Elektronik Belgelerin Imhası: Teori ve Uygulama başlıklı kitap, yazarın 2019 yılında tamamladığı "Elektronik Belgelerin ve Elektronik Belgelere Ait İşlem İzlerinin Arşiv İmha Uygulamaları Bakımından İncelenmesi” başlıklı doktora tezine dayanmaktadır. 2020 yılında "Elektronik Belgelerin İmhası: Teori ve Uygulama" adıyla yayımlanan kitap, kamu kurum ve kuruluşlarındaki imha edilmesi gereken elektronik belgelerinin imhası, belgelere ait işlem izlerinin hangi yöntem ve tekniklerle imha edileceği, dünyada ve Türkiye'de belge imha uygulama ve politikaları ve mevcut durumla ilgili bilgi vermekte; buna ek olarak Türk arşivcilik literatüründe eksikliği hissedilen bir konu olan elektronik imha yöntem ve teknikleri ile ilgili boşluğu doldurmaya yardımcı olmaktadır. Ayrıca, bu kitap arşivsel değerlendirme ve arşiv imha teorilerinin incelenmesi açısından önemli bir anlam taşımaktadır.

Beş ana bölümden oluşan kitabın "Giriş” kısmında araştırmanın önemi, amacı, kullanılan yöntemler, cevap aranan sorular, çalışmadan beklenen sonuçlar ve birincil kaynaklar belirtilmiştir. 
Kitabın ilk bölümü “Arşivsel Değerlendirme” başlığını taşımaktadır. Yazar, arşivsel değerlendirmenin geniş bir açıklamasını yapmakta ve değişen dünya şartlarının dijital arşiv uygulamaları açısından önemli yenilikler taşıdığını ifade etmektedir. Ardından, “Avrupa' da geleneksel arşivsel değerlendirme anlayışı” başlığı altında Almanya, Birleşik Krallık, Amerika Birleşik Devletleri (ABD) ve Avusturalya'daki arşivsel değerlendirme anlayışlarından ve tarihsel gelişimlerinden bahsetmiştir. Böylelikle imhanın dünyadaki varoluş serüvenine işaret edilmiştir.

Kitabın ikinci bölümü, "Elektronik Belge Yönetim Sistemi Modelleri” başlığını taşımaktadır. Arşivsel uygulama eğilimleri arasındaki yaklaşım farklılıkları ve bu yaklaşım farklılıklarının getirmiş olduğu belge yönetim modellerinden söz edilmiştir. Dünyada yaygın olan üç temel belge yönetimi modeli detaylı incelenmiştir. Elektronik ortamdaki imha konusunun detaylı bir biçimde kavranmasını sağlayacak olan bu modeller;

- Avrupa İdari Modeli - Arşivsel Model (European Administrative Model-Archival Model),

-Anglo-Sakson Modeli - Yaşam döngüsü Modeli (Anglo-Saxon Model - Lifecycle Model),

-Avustralya Modeli - Belge Sürekliliği Modeli (Australian Model - Records Continuum)

başlıkları altında açıklanmıştır. Bölümün alt başlıkları altında bu modellerin sistem özellikleri, ayrıntı aşamaları ile yönetim süreçlerinden bahsedilmiştir. Modellerin, belge yönetimi ve arşiv uygulamalarının çatısını oluşturması sebebiyle ayrıntılı şekilde ele alınması tercih edilmiştir.

İlk model olarak “Avrupa İdari Modeli - Arşivsel Model” ele alınmıştır. Bu kısım Avrupa arşivsel sistemlerini yansıtması bakımından değerlidir. Doküman kelimesinin belge ile aynı anlamı taşımasından, doküman yaşam döngüsünün iki aşamasından ve teknolojik gelişimlere paralel olarak Avrupa arşiv modelinin yeniden şekillenmesinden söz edilmiştir. Bu bağlamda geliştirilmiş MoReq modeli 2001 yılında yayınlanmıştır. 2008 yılında modelin güncellenmiş olan sürümü MoReq2 yayınlanmıştır. Avrupa arşivsel modeli olarak Moreq2010, MoReq2'nin devamı olarak 2010 yılından beri kullanılmaya devam edilmektedir. 2010 yılından itibaren bu yapı tüm Avrupa Birliği ülkelerinin kurum ve kuruluşlarında kullanılmaktadır. MoReq2010 varlıklar ve varlık ilişkileri kısmında "kümeleme (aggregation)"den yeni bir kavram olarak bahsedilmiştir. Kümeleme kavramı yapılanmış bileşenler topluluğu, belge varlıklarının birikimi olarak tanımlanmıştır. Belgelerin kümelenmesine ek olarak belge yönetim sistemlerinde bütün belgelerin bir üst veriye sahip olması gerektiğinden söz edilmiştir. Üst verinin MoReq modeli ve tüm EBYS'ler için anlamı ve önemi vurgulanmıştır.

İkinci model olarak “Anglo-Sakson modeli - Yaşam Döngüsü Modeli” incelenmiştir. Model, önce Amerikan Ulusal Arşivinden Philip Coolidge Brooks ve Emmett J. Leahy tarafından tasarlanmış, daha sonra Ira A. Penn tarafından geliştirilmiştir. Anglo-Sakson modeli, belge yönetimi için yaşam döngüsünü ifade etmektedir. Bir belgenin yaşam döngüsü (1) üretim, (2) 
düzenleme, kullanım ve koruma ile (3) değerlendirme ve imha aşamalarından oluşmaktadır. Yaşam döngüsü modelinde bilgi akışı aşamaları açıklanmış, elektronik olarak gelişen belge yönetimi sürecinde bilginin yönetilmesi hususunda bilgiler verilmiştir.

Üçüncü ve son model olarak; “Avustralya Modeli - Belge Sürekliliği Modeli” ele alınmıştır. Bu model, elektronik belge yönetiminin Avusturalya'ya özgü gelişme sürecini yansıtmaktadır. Frank Upward'ın ve Jay Atherton'ın görüşlerinden de etkilenilerek geliştirilen bu model; belge sürekliliği (record continuum), belge, kanıt, işlem ve belge üreticisinin kimliği ile örtüşen unsurlarını ele alan bir yaklaşım olarak ifade edilmiştir. Belgelerin birincil ve ikincil olarak farklı değerlere sahip olduğundan ve (1) belge üretimi, (2) kanıt değeri, (3) işlem ve (4) üretim sorumluluğunun tanımlanması şeklinde ifade edilen sürecin dört aşamasından söz edilmiştir. $\mathrm{Bu}$ aşamalar incelendiğinde süreklilik modelinin farklı boyutlarının da ortaya çıkmış olduğu yazar tarafından ifade edilmiştir. Her bir aşamanın işlem sürekliliği ve kontrol süreçleri detayları ile tanıtılarak bilgi verilmiştir. Süreklilik modelinin detaylı irdelenmesi sonucu yazar "Belge yönetiminin süreklilik modelindeki rolü nedir?” sorusunun cevabını şu şekilde vermiştir:

• Yönetişimi kolaylaştırmak.

- Hesap verilebilirliği kolaylaştırmak.

- Ortak ve kurumsal bilgiyi tutmak.

- Hem kişisel hem de ortak kimliğin kanıtlarını sağlamak.

- Varlık olarak yararlanılan bilgilerden ve süreç içinde üretilen belgelerden katma değerli bilgiler sağlamak.

Kitabın üçüncü bölümü, "Elektronik Belgelerin Varlığının Yazılım ve Donanım Yönü ve Bu Yönlere Ait İzler” başlığını taşımaktadır. Bu bölüm “Elektronik Belge Yönetim Sistemleri”, "Elektronik Belge Yönetim Sistemlerine İlişkin Yazılım İzleri”, "Elektronik Belge Yönetim Sistemlerine İlişkin Donanım İzleri” olmak üzere üç alt başlıkla detaylandırılmıştır. Elektronik belgeye ilişkin tüm yazılım-donanım izlerinin yok edilmesi ve iz bırakılmamasına ilişkin yapılacak işlemler etraflıca anlatılmıştır. Belge izlerinin bulunduğu olası yerler ve ne şekilde imha edileceklerinden, yazılımsal izler yok edilirken depolama alanlarının sadece yazılımsal olarak değil fiziki olarak da yok edilmesi gereğinden bahsedilmiştir. Elektronik belgenin imhası gerçekleşirken ortaya çıkan hukuki güvenlik şartları ve adli bilişim ile ilişkisine de yer verilmiştir.

Kitabın dördüncü bölümü “Dünyada ve Türkiye'de Elektronik Belge İmha Politikaları, Teorileri ve Uygulamaları" başlığına sahiptir ve beş kısımdan oluşmaktadır. Bu bölümde dünyadaki ve Türkiye'deki imha yöntemlerine yönelik politikalar ve sorumluluklar ile bu konuda yapılan çalışmalara yer verilmiştir. 
Dördüncü bölümün “Elektronik Belge İmhasına Yönelik Uluslararası Düzenlemeler” alt başlığında Almanya, ABD, Avusturalya, İngiltere, Rusya ve Kanada’nın geliştirdiği birçok düzenleme ve standartlar ayrıntılarıyla yer almıştır. Yazar, "Elektronik Belge Yönetimine İlişkin Uluslararası Standartlarda ve Düzenlemelerde İmha Uygulama Göstergeleri” alt başlığıyla devam ederek belge yönetimi süreçlerindeki farklılıklardan, ülkelerin ihtiyaçlarına göre benimsenmiş yapılardan bahsetmiş ve belge yönetiminde imha standartları, elektronik belge yönetimine özgü standartlar, üst veri, analiz standartları, yazılım uygulamaları, format standartları adı altında hazırlanmış yönetim sistem ve standartlarını açıklamıştır. Ardından “İmha Uygulamaları İçin Geliştirilen Uluslararası Yazılımlar” alt başlığında imha yazılımlarının kullandıkları yöntem ve teknikler yazar tarafından hazırlanmış bir tablo ile gösterilmiştir. “Türkiye’deki Düzenlemeler” alt başlığında ise geçmişten günümüze ülkemizdeki belgelerle ilgili düzenleme, saklama, koruma ve imha düzenlemeleri ve uygulamalarından söz edilmiştir. Dördüncü bölümün son başlığı olan “Kurumların Arşivsel İmhaya Yönelik Algısı” kısmında yazar, kamu kurum ve kuruluşlarında üretilen belgelere yönelik nasıl bir imha uygulaması benimsenmesi gerektiğinden bahsederek, ülkemizde konuya ilişkin bağlayıcı bir arşiv kanununun olmamasının olumsuzluklara yol açabileceğini; buna bağlı olarak da arşiv imha teorisinin uygulanmasının zorlaşacağını belirtmiştir.

Kitabın beşinci ve son bölümü “Elektronik Belgenin İmhasına Yönelik Yöntem ve Teknikler” başlığını taşımakta ve üç alt başlıkta detaylandırılmaktadır. Bu bölüm, elektronik belge ve imha, adli bilişim araçları ve bunların elektronik belge imhasıyla ilişkisi ve vaka analizleri alt başlıkları ile incelenmiştir.

Beşinci bölümün ilk kısmında belgelerin imhasına yönelik kullanılan yöntemler güncel ortamda bulunan belgeler ve güncelliğini yitirmiş belgeler (obsolete) olarak iki ayrı şekilde irdelenmiştir. Güncel ortamda bulunan elektronik belgelere yönelik imha teknikleri; tasfiye (disposal), arındırma (clearing), temizleme (purging) ve imha etme (destroying)' dir. Yazar söz konusu veri temizleme metotlarının güvenlik farklılıklarına ve işlemlerin gerçekleştirilme süreçlerine dair karşılaştırmaları tablo halinde belirtmiş, tekniklerin tanımı ve nasıl işlediği ile ilgili açıklamalara yer vermiştir. Yazar, güncelliğini yitirmiş belgelerin imha teknikleri ve yöntemleri kısmında; güncel ortamdaki belgelerle benzerlik göstermesinin yanında belgeyle beraber ortamın da imha edilmesi gerektiği üzerinde durmuştur. Bu bağlamda başvurulan yöntem ve teknikler; erişime kapatma (deaccessioning), geri dönüşüme uygun hale getirme, taşlama veya firçalama (grinding or scrubbing), çekiçli değirmenle imha etme (hammermilling), parçalama (disintegration), ufalama (shredding), yakma (incineration), kesme (cutting), salamuralaşma (dry maceration), eritme (smelting), kimyasal imha ve elektronik atık olarak sıralanmış ve her bir yöntemin açıklaması yapılmıştır.

Beşinci bölümün ikinci alt başlığı olan “Adli Bilişim Araçları ve Bunların Elektronik Belge İmhasıyla İlişkisi” kısmında, önce adli bilişimin tanımı yapılmış, ardından adli bilişimin 
ülkemizdeki yasal çerçevesi ile arşivciler ve belge yöneticileri için adli bilişimin belge yönetim ve imha süreçlerinde tamamlayıcı bir unsur olduğu üzerinde durulmuştur. Buna ilaveten adli bilişim araçlarında kullanılan algoritmalar; Hash algoritmaları ve Hamming ve Golay algoritmaları (ECC) da bu alt başlıkta açıklanmıştır.

Beşinci bölümün son kısmı vaka analizleri (İmhaya Yönelik Örnekler) alt başlığına ayrılmış ve vaka örneği verilmiştir.

Kitabın "Sonuç" bölümünde ise önceki bölümlerde bahsedilen konulara yönelik değerlendirme yapılmış ve çeşitli çözüm önerileri yazar tarafından ortaya konulmuştur. Bu bağlamda kabul görmüş arşiv ilkelerine dayanan uygulamaların bilgi ortamının ve belge türlerinin çeşitlenmesiyle yeni uygulamaların ortaya çıkması ve arşivsel değerlendirmenin önemi vurgulanmıştır. Türkiye'nin arşivsel değerlendirme noktasında Almanya, İngiltere ve ABD'deki uygulama modellerinden etkilendiğinden söz edilmiştir. Ülkemizdeki belge yönetimi ve arşiv hizmetlerine yönelik yasal düzenlemelerin sürekli değiştiği ve bu değişimlerin bir bütün oluşturamadığı, bu nedenle elektronik ortam için ulusal bir imha teorisinin henüz sunulamamış olduğu dile getirilmiştir. Yazar, Türkiye'de kamu kurum ve kuruluşlarında elektronik belge ve arşiv uygulamaları için imha yöntemlerinin tasarlanması gerekliliğini vurgulamıştır. İhtiyaç duyulan yazılımın geliştirilmesi ve EBYS içinde kullanılmasının mümkün hale getirilmesi önerisinde bulunmuştur. Bu bağlamda yazılımın geliştirilmesi noktasında kurumların ortak bir çalışma yürütebileceği üzerinde durulmuştur. Öncelikli olarak Devlet Arşivleri Başkanlığı ve Adalet Bakanlığının ortak çalışmalarıyla kamu kurum ve kuruluşlarında (kurum arşivlerinde) imha edilmesi gerekli olan belgeler için imha kodlarının belirlenmesi, TÜBİTAK ve BTK (Bilgi Teknolojileri ve İletişim Kurumu)'nın teknik destek noktasında katkıda bulunması, askeri kurumlar için ASELSAN'ın bilgi ve tecrübelerinden faydalanılabileceği konusuna değinilmiştir. Ayrıca bu konuda bilinçlendirme süreçleri kapsamında Milli Eğitim Bakanlığı ve Devlet Arşivleri Başkanlığı işbirliği ile sınıf içi ve sınıf dışı ders ortamlarında ve hatta üniversitelerde konuya dair ortak çalışmalar yürütülebilmesi önerileri sunulmuştur.

Ciddi bir analize dayanan bu kitap belge yönetimi ve arşivcilik alanında çalışan araştırmacılar için önemli bir başvuru eseri niteliği taşımaktadır. 
